\title{
Article \\ Inhibition of Four Inert Powders on the Minimum Ignition Energy of Sucrose Dust
}

\author{
Yuankun Zhong ${ }^{1}\left(\mathbb{D}\right.$, Xiaoquan $\mathrm{Li}^{1,2, *(\mathbb{D}}$, Juju Jiang ${ }^{1}$, Siting Liang ${ }^{1}$, Zhiwen Yang ${ }^{1}$ and Jeffrey Soar ${ }^{2}(\mathbb{D}$ \\ 1 School of Resources, Environment and Materials, Guangxi University, Nanning 530004, China; \\ zykgxu@163.com (Y.Z.); jiangju.ju@foxmail.com (J.J.); scoutqaq@163.com (S.L.); yzwgxu@163.com (Z.Y.) \\ 2 School of Business, University of Southern Queensland, Toowoomba 4350, Australia; jeffrey.soar@usq.edu.au \\ * Correspondence: 1xq0927@gxu.edu.cn
}

Citation: Zhong, Y.; Li, X.; Jiang, J.; Liang, S.; Yang, Z.; Soar, J. Inhibition of Four Inert Powders on the Minimum Ignition Energy of Sucrose Dust. Processes 2022, 10, 405. https://doi.org/10.3390/pr10020405

Academic Editor: Chi-Min Shu

Received: 18 January 2022

Accepted: 16 February 2022

Published: 18 February 2022

Publisher's Note: MDPI stays neutral with regard to jurisdictional claims in published maps and institutional affiliations.

Copyright: (c) 2022 by the authors. Licensee MDPI, Basel, Switzerland. This article is an open access article distributed under the terms and conditions of the Creative Commons Attribution (CC BY) license (https:// creativecommons.org/licenses/by/ $4.0 /)$.

\begin{abstract}
In order to evaluate the effect of inert powder on the ignition sensitivity of sucrose dust this study investigated the effects of $\mathrm{NaHCO}_{3}, \mathrm{NaCl}, \mathrm{NH}_{4} \mathrm{H}_{2} \mathrm{PO}_{4}$ and $\mathrm{Al}(\mathrm{OH})_{3}$ on the minimum ignition energy (MIE) of sucrose dust. The results showed that all four different inert powders inhibited the MIE of sucrose dust, and all of them showed a trend that the smaller the particle size of the inert powders, the better the inhibition effect. The inhibition effect was ranked as $\mathrm{NaHCO}_{3}>\mathrm{NH}_{4} \mathrm{H}_{2} \mathrm{PO}_{4}>\mathrm{NaCl}>\mathrm{Al}(\mathrm{OH})_{3} . \mathrm{NaHCO}_{3}$ and $\mathrm{NH}_{4} \mathrm{H}_{2} \mathrm{PO}_{4}$ had both physical and chemical inhibition effects, which were better compared to $\mathrm{NaCl}$ and $\mathrm{Al}(\mathrm{OH})_{3}$, which had only physical inhibition effects. Analysis of the flame images showed that the inert powder slowed down the combustion of the sucrose dust flame and reduced the flame height. No flame appeared in the region of higher inert powder concentration.
\end{abstract}

Keywords: sucrose dust explosion; inhibition; minimum ignition energy; particle size; inert powder

\section{Introduction}

Sucrose is an important household product. Sucrose dust is combustible as well as non-conductive and can be defined as Class IIIB dust according to the standard ISO/IEC 80079-20-1. During the sucrose production process, sucrose dust is prone to flying and accumulating in the sucrose factory floor. According to IEC 60079-10-2, the dust explosive environment can be divided into: Zone 20, Zone 21 and Zone 22. Zone 20 has the highest level of danger, and it refers to places where explosive atmospheres exist continuously, permanently or frequently, in the form of clouds of combustible dust in the air, generally inside vessels, pipes, tanks, etc. Under certain conditions, sucrose dust clouds can explode, such as in 2008 when a fire inside a closed conveyor belt pipe in the production plant of Imperial Sugar Co. in Port Wentworth, USA, ignited sucrose dust, which in turn produced an explosion that killed 14 people and injured 36 others [1].

Dust explosions are a major focus in the field of industrial process safety [2]. In recent years, many scholars have conducted numerous studies on the suppression of various types of dust explosions and have achieved certain results [3-9]. In order to reduce the risk and probability of dust explosion, the addition of inert powders to combustible dusts can reduce the ignition sensitivity of combustible dusts or terminate dust explosions. Different types of inert powders often have different inhibitory effects. Wang et al. [10] studied the inhibitory effect of $\mathrm{Al}(\mathrm{OH})_{3}, \mathrm{Mg}(\mathrm{OH})_{2}$ and $\mathrm{NaHCO}_{3}$ on colored organic dusts, and proved that these three powders can inhibit the explosion of colored organic dusts. Among these, $\mathrm{NaHCO}_{3}$ has the best effect, which is due to its lower decomposition temperature and its release of carbon dioxide which can effectively reduce the oxygen concentration in the system. Chen et al. [11] added $\mathrm{NaHCO}_{3}$ to aluminum powder and found that it could reduce the thickness of the flame reaction zone and weaken the flame propagation rate. Lin et al. [12] studied the effect of four inert powders $\left(\mathrm{NaHCO}_{3}, \mathrm{NaC}_{2} \mathrm{O}_{4}, \mathrm{KHCO}_{3}\right.$ and $\left.\mathrm{K}_{2} \mathrm{C}_{2} \mathrm{O}_{4}\right)$ on the minimum ignition energy (MIE) and minimum ignition temperature of polyethylene dust, 
and found that the suppression effect of bicarbonate dust was better than that of oxalate dust. Jiang et al. [13] studied the inhibition effect of $\mathrm{NaHCO}_{3}$ with different particle sizes on the explosion of aluminum powder and concluded that $\mathrm{NaHCO}_{3}$ hinders the explosion of aluminum powder by both physical inhibition and chemical inhibition; however, they compared the inhibition of combustion of aluminum powder by $\mathrm{NH}_{4} \mathrm{H}_{2} \mathrm{PO}_{4}$ and $\mathrm{NaHCO}_{3}$ and pointed out that $\mathrm{NH}_{4} \mathrm{H}_{2} \mathrm{PO}_{4}$ has a better inhibition effect [14]. Zhao et al. [15] studied the inhibitory effect of $(\mathrm{NH} 4)_{2} \mathrm{HPO}_{4}$ on the explosion of wheat dust and found that as the concentration of diammonium hydrogen phosphate increased, the ionic current in the explosion reaction zone of wheat dust first increased and then decreased, which could consequently inhibit the explosion of wheat dust. Xu and Jiang [16] compared the inhibitory effects of $\mathrm{NaCl}, \mathrm{SiO}_{2}$ and $\mathrm{SiC}$ on aluminum-methane-air flames, and $\mathrm{NaCl}$ had the best inhibitory effect, significantly slowing down the flame propagation. Lin et al. [17] found experimentally that $\mathrm{Al}(\mathrm{OH})_{3}$ could inhibit polyethylene dust explosion, and when the mass fraction of $\mathrm{Al}(\mathrm{OH})_{3}$ powder reached above $80 \mathrm{wt} \%$, it could inhibit polyethylene flame propagation. Wang et al. [18] studied the suppression effect of $\mathrm{Al}(\mathrm{OH})_{3}$ and $\mathrm{Mg}(\mathrm{OH})_{2}$ powder on the explosion of aluminum and magnesium alloy dust, and found that the suppression effect of $\mathrm{Al}(\mathrm{OH})_{3}$ was better when the mass fraction of inert powder was small; when the mass fraction of inert powder was larger, the suppression effect of $\mathrm{Mg}(\mathrm{OH})_{2}$ was better than that of $\mathrm{Al}(\mathrm{OH})_{3}$. According to the existing studies, carbonates and phosphates have good inhibition effects on different kinds of dusts, while substances commonly used as inorganic flame retardants, such as $\mathrm{NaCl}$ and $\mathrm{Al}(\mathrm{OH})_{3}$, have also shown inhibition effects on dust combustion.

The particle size of the inert powder is also a key factor influencing its effectiveness in suppressing dust explosion [19-21]. Jin et al. [22] studied the effect of particle size of alumina on the explosion of aluminum powder, and the results showed that the chemical inhibition of the thermal radiation process by alumina is its main inerting mode, and the smaller the particle size of alumina, the better its inhibition effect. Jiang et al. [23] found that $\mathrm{NH}_{4} \mathrm{H}_{2} \mathrm{PO}_{4}$ particles of different particle sizes can affect the flame morphology of aluminum dust, and fine particles of $\mathrm{NH}_{4} \mathrm{H}_{2} \mathrm{PO}_{4}$ can produce a more adequate chemical reaction in the flame than the flame itself. Therefore, it is important to study the inhibition mechanism of inert powders and the effect of their particle size on combustible dusts. However, few researchers have systematically studied the effects of inert powders on the flame of sucrose dust, and the inhibition mechanism of inert powders on the flame of sucrose dust has not been investigated.

Qin and $\mathrm{Li}$ [24] tested the effects of $\mathrm{NH}_{4} \mathrm{H}_{2} \mathrm{PO}_{4}$ and $\mathrm{Al}(\mathrm{OH})_{3}$ on the combustion of sucrose dust by separately testing the effects of $\mathrm{NH}_{4} \mathrm{H}_{2} \mathrm{PO}_{4}$ and $\mathrm{Al}(\mathrm{OH})_{3}$ in different particle size states, and found that both inert powders could inhibit the combustion of sucrose dust. They found that $\mathrm{NH}_{4} \mathrm{H}_{2} \mathrm{PO}_{4}$ had physical inhibition and chemical inhibition, and its inerting ability was significantly better than that of $\mathrm{Al}(\mathrm{OH})_{3}$. Wang et al. [25] studied the effect of $\mathrm{NaCl}$ on the combustion of different mass fractions of sucrose dust, and the results showed that the inhibition effect of $\mathrm{NaCl}$ dust with a particle size larger than $75 \mu \mathrm{m}$ was not good, whereas the inhibition ability of $\mathrm{NaCl}$ with 38-47 and 48-74 $\mu \mathrm{m}$ was better, and the inhibition effect was relatively close. In the previous study, the discussion of the inhibition effect of inert powders in sucrose dust was not targeted enough. Some experimental conditions were inconsistent and the differences in the inhibition ability of various types of inert powder were not discussed systematically. Therefore, in this paper, based on the existing studies [24,25], we set the same experimental conditions, added carbonates for experiments, and used $\mathrm{NaHCO}_{3}, \mathrm{NaCl}, \mathrm{NH}_{4} \mathrm{H}_{2} \mathrm{PO}_{4}$ and $\mathrm{Al}(\mathrm{OH})_{3}$ with different particle sizes for minimum ignition energy experiments in order to compare their inhibitory effects on the ignition sensitivity of sucrose dust. 


\section{Experimental Section}

\subsection{Experimental Apparatus}

The experimental system consisted of 1.2 L Hartmann apparatus, high-speed photography system, high-pressure ignition system and data acquisition system, as shown in Figure 1. 1.2 L Hartmann apparatus can provide ignition energy from $0.1 \mathrm{~mJ}$ to $1000 \mathrm{~mJ}$, the ignition method is electric spark ignition, the inductance of the discharge circuit is $1 \mathrm{mH}$, and its main body is a vertically placed quartz glass tube, $300 \mathrm{~mm}$ high, circular crosssection, with a cross-section radius of $35.7 \mathrm{~mm}$. It has the advantages of small size, easy disassembly, easy cleaning of combustion residue, short experiment time among others.

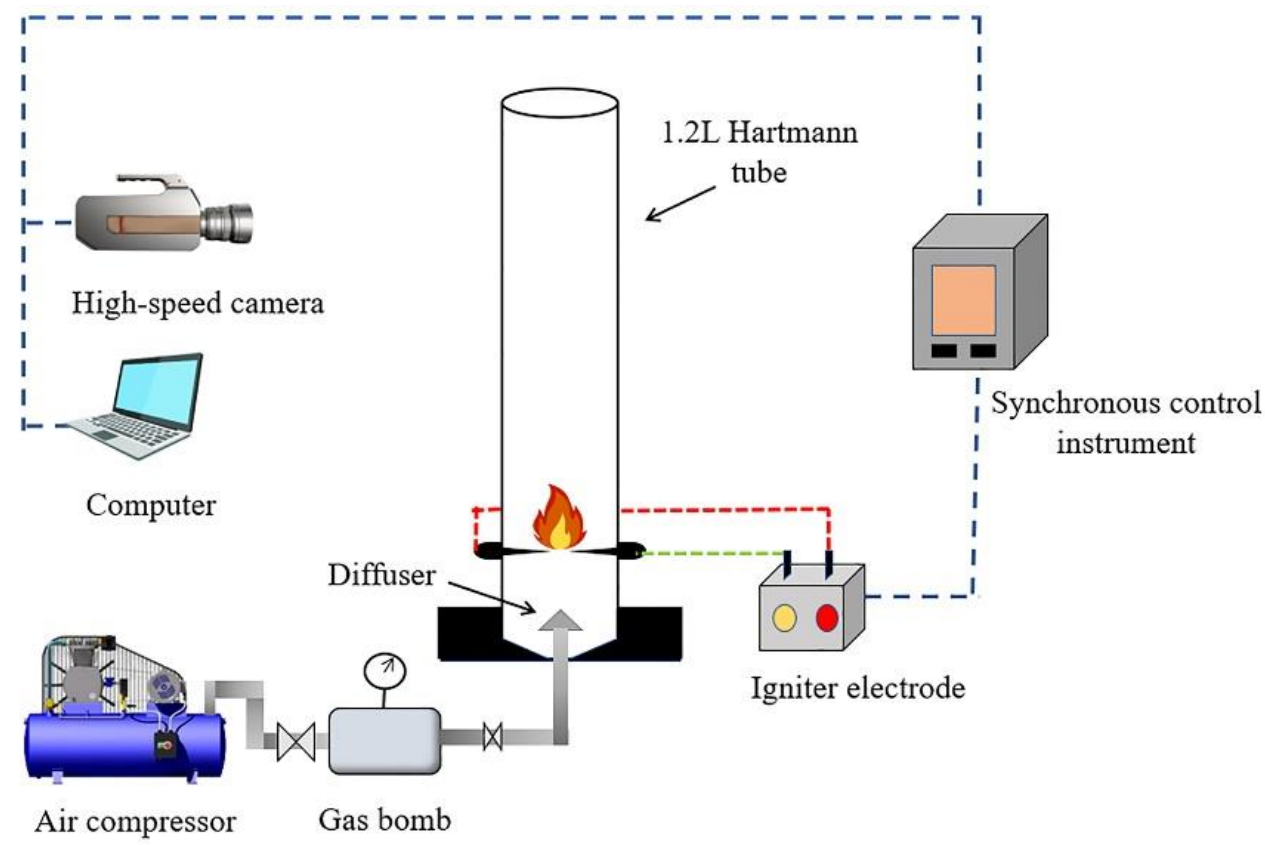

Figure 1. Schematic diagram of experimental apparatus.

\subsection{Experimental Materials}

Analytically pure $\mathrm{NaHCO}_{3}, \mathrm{NH}_{4} \mathrm{H}_{2} \mathrm{PO}_{4}, \mathrm{NaCl}$ and $\mathrm{Al}(\mathrm{OH})_{3}$ powders were used as inert powders and sucrose dusts were used as combustible dusts. The four inert powders were sieved through standard analytical sieves, and the set particle size ranges were 25-37, 38-47 and 48-74 $\mu \mathrm{m}$, respectively, and 48-74 $\mu \mathrm{m}$ for sucrose dust. Before the test, all samples were dried in an electric drying oven for $12 \mathrm{~h}$ and then stored in a drying bottle. The samples were mixed manually and the nominal amount of each sample was placed in a glass beaker and stirred with a glass rod, and the sample preparation was completed when the mixed materials showed no obvious signs of separation.

\subsection{Experimental Method}

Li et al. [26] tested the sucrose dust MIE and found that the smallest value of MIE of $55.8 \mathrm{~mJ}$ was obtained when the sucrose dust was at a mass concentration of $417 \mathrm{~g} / \mathrm{m}^{3}$ and an ignition delay time of $90 \mathrm{~ms}$. Therefore, we will add inert powder to this condition for the experiment. The experiments were carried out in the apparatus shown in Figure 1 to test the effects of four inert powders $\left(\mathrm{NaHCO}_{3}, \mathrm{NH}_{4} \mathrm{H}_{2} \mathrm{PO}_{4}, \mathrm{NaCl}\right.$ and $\left.\mathrm{Al}(\mathrm{OH})_{3}\right)$ on the MIE of sucrose dust. The laboratory temperature was controlled at $20{ }^{\circ} \mathrm{C}$ and the relative humidity was $50 \%$. The mass concentration of sucrose dust was taken as $417 \mathrm{~g} / \mathrm{m}^{3}$, and four kinds of inert powders with different mass fractions and particle sizes were added for thorough mixing according to the gradient ratio of $5 \%$. Then, the mixed dust was put into the umbrella diffuser at the bottom of the 1.2 L Hartmann tube apparatus; then, the air compressor was started. Under the action of compressed air, the dust was dispersed in the Hartmann apparatus, ignited through the electrode, and the experimental phenomena 
were observed. At the same time, the high-speed camera took pictures of the flame pattern and determined whether the dust cloud was on fire, and the MIE value of the dust cloud was obtained. The ejection pressure of compressed air was set to $60 \mathrm{kPa}$, the ignition delay time was 90 ms, and the recording speed of the high-speed camera was 2000 frames/s.

Since the Hartmann apparatus for this experiment was manufactured according to the standard GB/T 16428-1996, we will refer to this standard to judge the fire of the sucrose dust. In the standard GB/T 16428-1996, it is required that "In the open test tube, the flame leaves the spark position propagation of at least $60 \mathrm{~mm}$ ", which is to prevent the ignition electrode from abnormal discharge or flame intensity from being too small to make a wrong judgment on whether the dust cloud is on fire. The MIE lies between $E_{1}$, the highest energy at which ignition fails to occur in 20 successive attempts to ignite the dust-air mixture, and $E_{2}$, the lowest energy at which ignition occurs within up to 20 successive attempts.

$$
E_{1}<\operatorname{MIE}<E_{2}
$$

\section{Results}

This section may be divided by subheadings. It should provide a concise and precise description of the experimental results, their interpretation, and the experimental conclusions that can be drawn.

\subsection{Effect of Inert Powder of Mass Concentration on MIE of Sucrose Dust}

As shown in Figure 2, $\mathrm{NaHCO}_{3}, \mathrm{NH}_{4} \mathrm{H}_{2} \mathrm{PO}_{4}, \mathrm{NaCl}$ and $\mathrm{Al}(\mathrm{OH})_{3}$ with particle sizes of 25-37 $\mu \mathrm{m}$ were selected as the inert powders and mixed with sucrose for ignition experiments, and the ignition energy change patterns in the four groups of dusts were obtained. After the addition of the inert powder, the MIE of sucrose increased, and with the increase in mass fraction of the inert powder, the MIE of all four groups of dusts increased monotonically. The data curves in the last interval all showed a sharp increase, reaching the critical state of fully suppressing the sucrose dust, which indicated that $\mathrm{NaHCO}_{3}, \mathrm{NH}_{4} \mathrm{H}_{2} \mathrm{PO}_{4}, \mathrm{NaCl}$ and $\mathrm{Al}(\mathrm{OH})_{3}$ all have an inhibitory effect on the MIE of sucrose dust $[27,28]$.

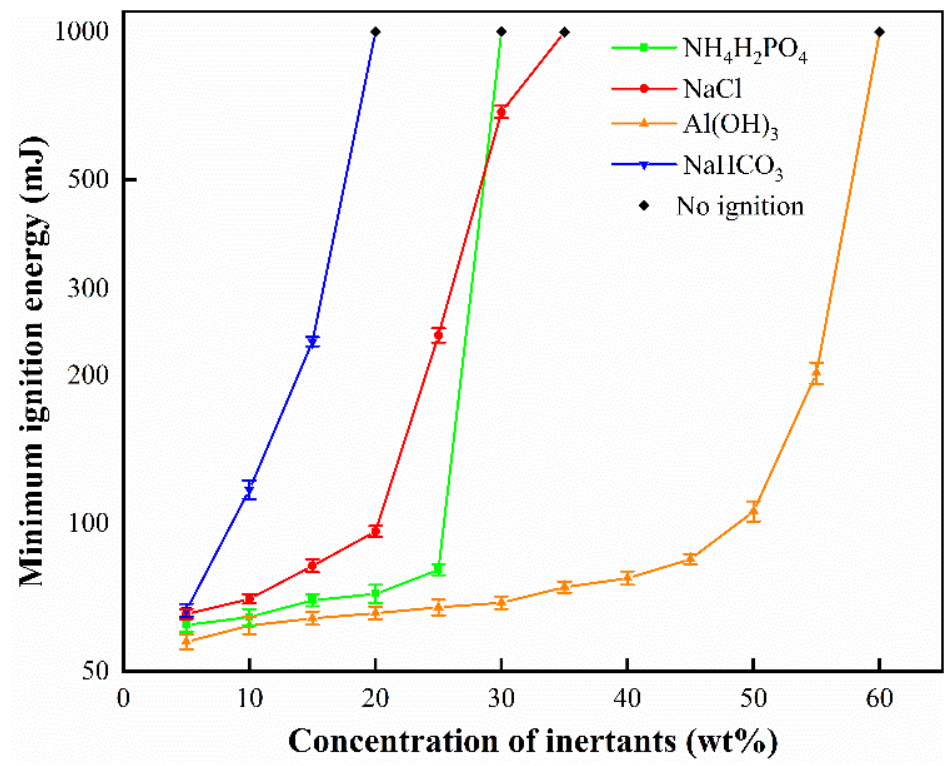

Figure 2. Effect of four inert powders in different mass concentration on sucrose dust.

As shown in Figure 2, $\mathrm{NaHCO}_{3}$ showed a better inhibitory effect on sucrose, and its mass concentration of $20 \mathrm{wt} \%$ made the sucrose dust unable to catch fire. The inhibitory effects of $\mathrm{NH}_{4} \mathrm{H}_{2} \mathrm{PO}_{4}$ and $\mathrm{NaCl}$ were similar, and the data curves of both groups did not fluctuate significantly when the mass fraction did not exceed $20 \mathrm{wt} \%$, and the MIE data did 
not exceed $100 \mathrm{~mJ}$; when the mass fraction of the inert powder was lower than $25 \mathrm{wt} \%$, the inhibition effect of $\mathrm{NaCl}$ was better than that of $\mathrm{NH}_{4} \mathrm{H}_{2} \mathrm{PO}_{4}$; when the mass fraction of inert powder was higher than $25 \mathrm{wt} \%$, the inhibition effect of $\mathrm{NH}_{4} \mathrm{H}_{2} \mathrm{PO}_{4}$ was better than that of $\mathrm{NaCl}$. Overall, the inhibition effect of $\mathrm{NH}_{4} \mathrm{H}_{2} \mathrm{PO}_{4}$ was slightly better than that of $\mathrm{NaCl}$. The inhibition effect of $\mathrm{Al}(\mathrm{OH})_{3}$ was poor: the MIE of the sucrose was always lower than $100 \mathrm{~mJ}$ at a mass fraction below $60 \mathrm{wt} \%$, indicating little effect on the ignition sensitivity of the sucrose. As a whole, the data curves for $\mathrm{Al}(\mathrm{OH})_{3}$ deviated to a larger extent compared to the other three inert powders. Therefore, a preliminary comparison of the inhibition ability of the four inert powders can be drawn: $\mathrm{NaHCO}_{3}>\mathrm{NH}_{4} \mathrm{H}_{2} \mathrm{PO}_{4}>\mathrm{NaCl}>\mathrm{Al}(\mathrm{OH})_{3}$.

\subsection{Effect of Inert Powder Particle Size on MIE of Sucrose Dust}

Under the same conditions as in 3.1,38-47 and 48-74 $\mu \mathrm{m}$ inert powders were added to sucrose dusts with a gradient of $5 \%$ mass fraction and mixed well, respectively. The experimental results are shown in Figure 3.
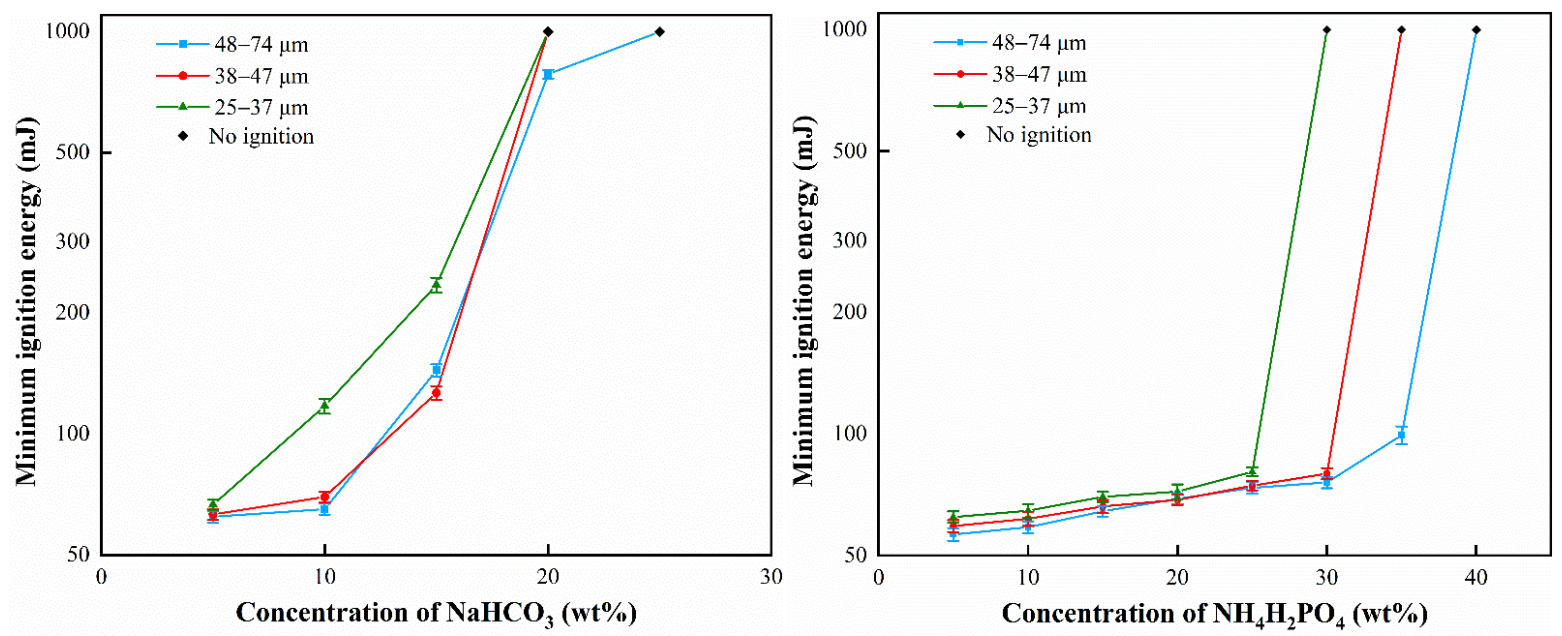

(a)

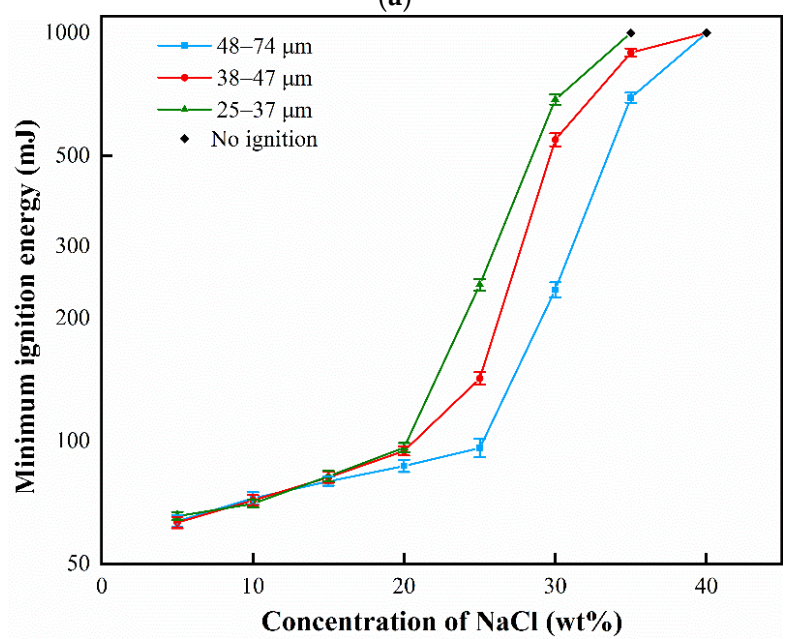

(c)

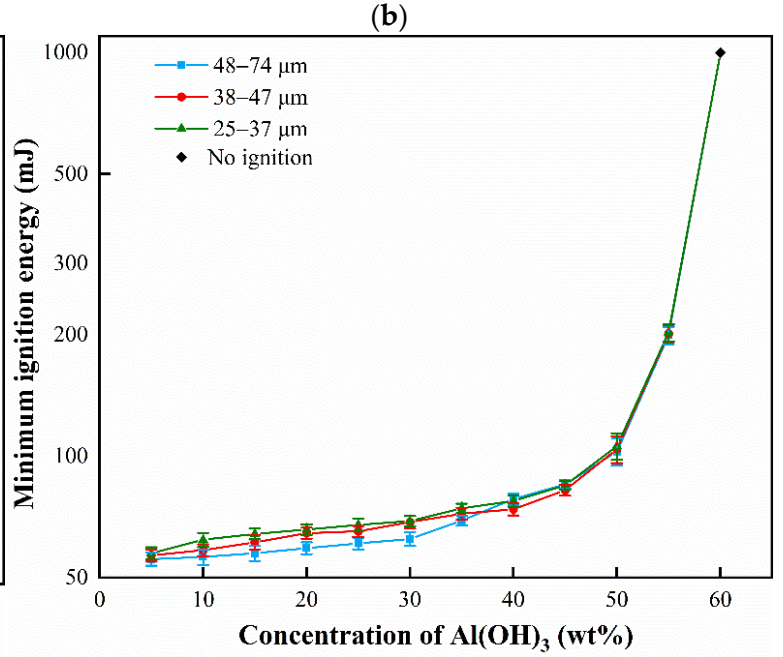

(d)

Figure 3. Effect of four inert powders with different particle sizes on sucrose MIE. (a) $\mathrm{NaHCO}_{3}$; (b) $\mathrm{NH}_{4} \mathrm{H}_{2} \mathrm{PO}_{4}$; (c) $\mathrm{NaCl}$; (d) $\mathrm{Al}(\mathrm{OH})_{3}$.

As shown in Figure 3, the smaller the particle size of the inert powder, the better the inhibition of sucrose combustion. Moreover, except for $\mathrm{Al}(\mathrm{OH})_{3}$, there is a significant difference in the inhibition ability of sucrose combustion for the other three inert powders with different particle sizes at the same mass fraction concentration. From Figure 3a, the inhibition effects of 25-37 and 37-48 $\mu \mathrm{m} \mathrm{NaHCO} 3$ were similar, and both eventually 
completely inhibited the sucrose dust at a mass fraction of $20 \mathrm{wt} \%$, but the change trend showed that $25-37 \mu \mathrm{m} \mathrm{NaHCO}$ had a better inhibition effect. From Figure $3 b$, it can be observed that the inhibition effect of $\mathrm{NH}_{4} \mathrm{H}_{2} \mathrm{PO}_{4}$ at three particle sizes on sucrose dust was not significant at low mass concentration of inert powder, but it was significantly enhanced when the inert powder content reached the critical point. From Figure $3 c$, the inhibition effect of $\mathrm{NaCl}$ on sucrose dust was similar to that of $\mathrm{NH}_{4} \mathrm{H}_{2} \mathrm{PO}_{4}$, and there was no significant effect of the difference in particle size on the inhibition when the percentage of $\mathrm{NaCl}$ was less than $15 \%$. In Figure 3d, although the MIE of the mixed dust increased slightly with the decrease in $\mathrm{Al}(\mathrm{OH})_{3}$ particle size, all three particle sizes of $\mathrm{Al}(\mathrm{OH})_{3}$ that made the mixed dust completely inert reached $60 \%$. It can be inferred that the inhibitory effect of $\mathrm{Al}(\mathrm{OH})_{3}$ increases with decreasing particle size, but the mass fraction concentration is independent of particle size.

\subsection{Effect of Inert Powder on Sucrose Flame}

Inert powder can inhibit the combustion of sucrose, which increases the MIE of sucrose, and on a macroscopic scale, it also has an effect on the flame formed by the combustion of sucrose. As shown in Figure 4, the flame pictures of the pure sucrose dust cloud, as well as the sucrose dust cloud mixed with different particle sizes of $\mathrm{NaHCO}_{3}$, were taken with a high-speed camera to analyze the flame state. In order to be able to clearly compare the direct differences of the flames, three sets of flame pictures with different particle sizes of $\mathrm{NaHCO}_{3}$ at a mass fraction of $10 \mathrm{wt} \%$ and ignition energy of $200 \mathrm{~mJ}$ were selected. The moment when the flame of the pure sucrose dust cloud appears as a more obvious flame was taken as the starting point, i.e., starting from $35 \mathrm{~ms}$ after the ignition electrode is discharged, and one picture was taken every $30 \mathrm{~ms}$ for comparison.

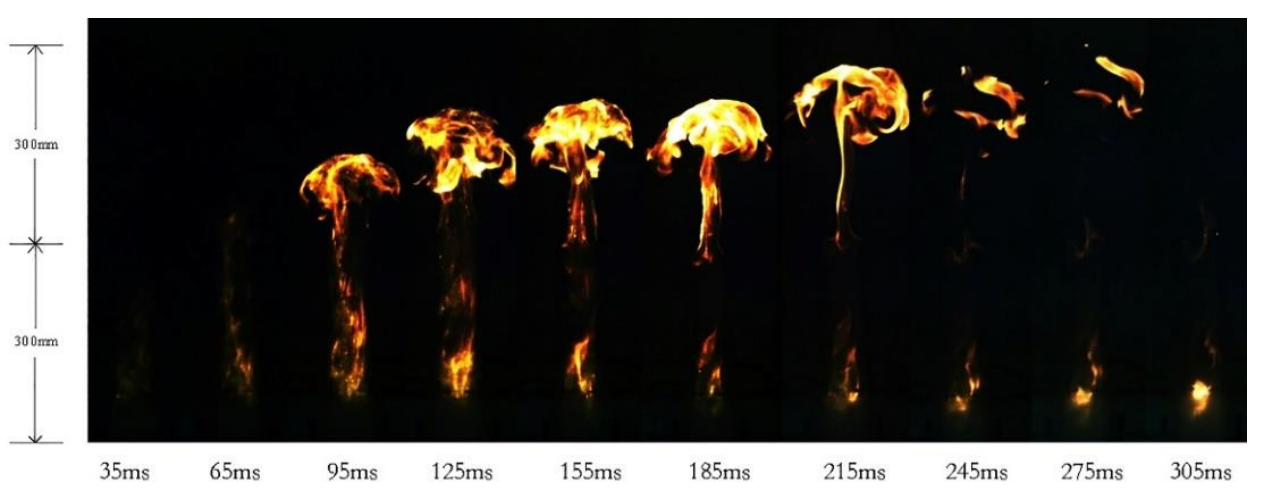

(a)

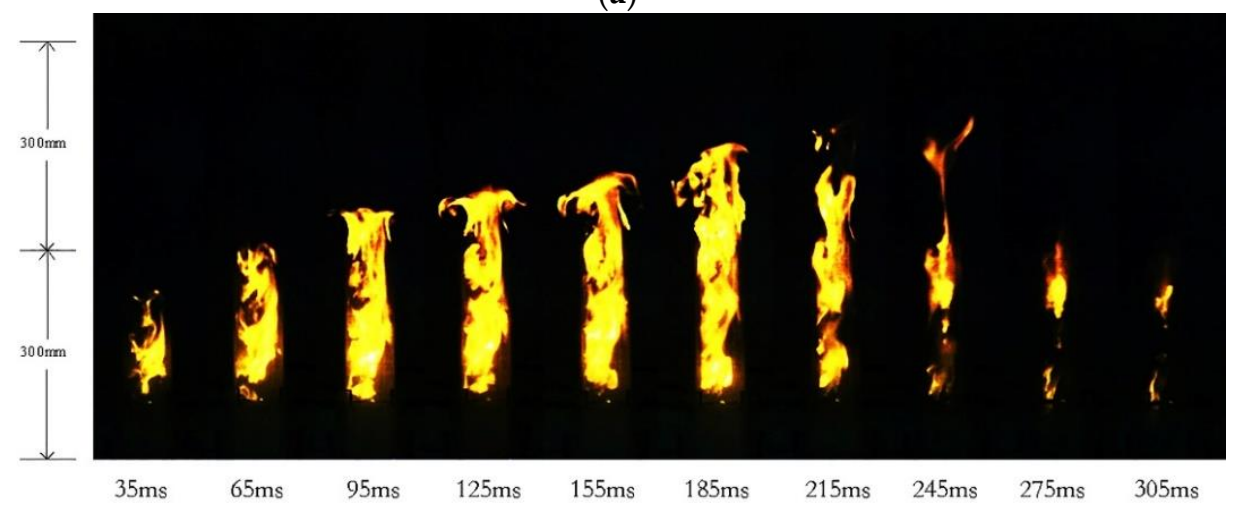

(b)

Figure 4. Cont. 


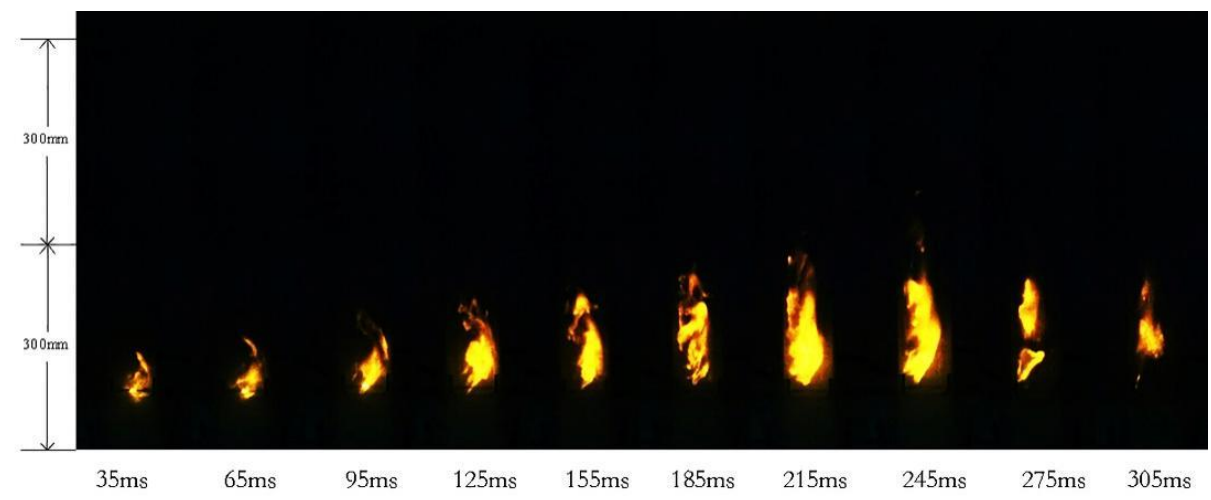

(c)

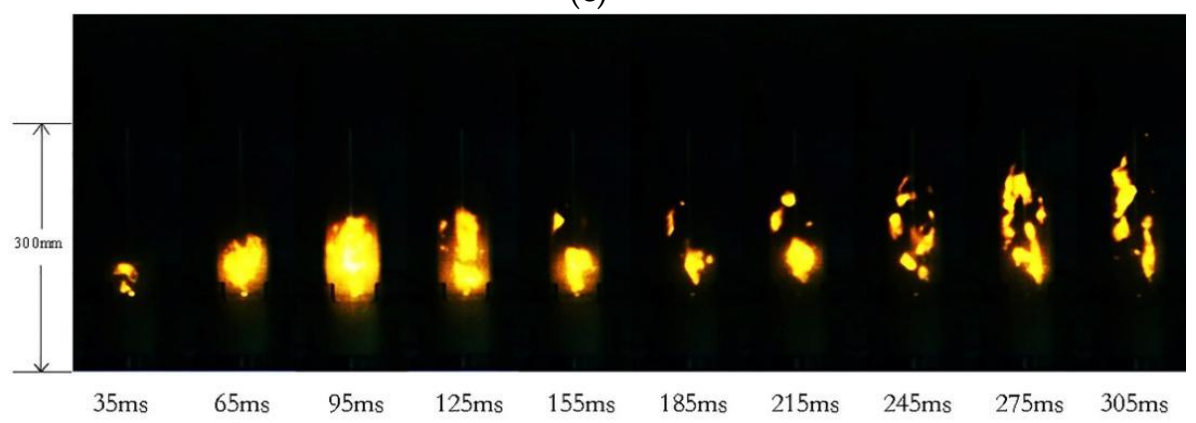

(d)

Figure 4. Flame diagram of sucrose dust under different conditions. (a) Sucrose dust; (b) sucrose dust with $10 \% \mathrm{NaHCO}_{3}$ added at $48-74 \mu \mathrm{m}$; (c) sucrose dust with $10 \% \mathrm{NaHCO}_{3}$ added at $38-47 \mu \mathrm{m}$; (d) sucrose dust with $10 \% \mathrm{NaHCO}_{3}$ added at $25-37 \mu \mathrm{m}$.

As shown in Figure 4, the flame color produced by the combustion of the sucrose dust cloud with $\mathrm{NaHCO}_{3}$ added was brighter than that of the pure sucrose dust cloud. Because $\mathrm{NaHCO}_{3}$ contains sodium, which has a yellow flame color reaction, and $\mathrm{NaHCO}_{3}$ dust was involved in the combustion process of the sucrose dust cloud, the yellow brightness of the flame during combustion of the sucrose dust containing $\mathrm{NaHCO}_{3}$ was higher.

The flame suppression effect of $\mathrm{NaHCO}_{3}$ on the sucrose dust cloud was significant. From Figure 4, it can be seen that the flame of the sucrose dust cloud burning with $\mathrm{NaHCO}_{3}$ was delayed in reaching the maximum peak compared to the sucrose dust cloud, and the flame intensity was weakened by $\mathrm{NaHCO}_{3}$ particle size in different degrees. From the flame images, it can be seen that the flame of the sucrose dust cloud was affected by $\mathrm{NaHCO}_{3}$, which shows that the flame was discontinuous and dispersed at the macroscopic level, and the smaller the particle size of $\mathrm{NaHCO}_{3}$ dust, the more obvious the flame dispersion was. This may be due to the fact that $\mathrm{NaHCO}_{3}$ hinders the heat conduction and thermal radiation processes between sucrose dusts, and the combustion is not uniform and sufficient. In addition, the flame height of the sucrose dust cloud decreased in the presence of $\mathrm{NaHCO}_{3}$ : the maximum flame height of the sucrose dust cloud was about $600 \mathrm{~mm}$, the maximum flame height of the dust cloud with 48-74 $\mu \mathrm{m} \mathrm{NaHCO} 3$ was about $500 \mathrm{~mm}$, the maximum flame height of the dust cloud with 38-47 $\mu \mathrm{m} \mathrm{NaHCO}_{3}$ was about $350 \mathrm{~mm}$, and the maximum flame height of the dust cloud with 25-37 $\mu \mathrm{m} \mathrm{NaHCO} 3$ was about $280 \mathrm{~mm}$. This is because $\mathrm{NaHCO}_{3}$ hinders the thermal decomposition process of dust particles in the process of dust combustion formation, which leads to a decrease in the production of combustible gas mixture of sucrose dust and reduces the amount of combustible gas mixture involved in combustion, so that the flame height of the sucrose dust cloud is reduced on a macroscopic scale, and the finer the $\mathrm{NaHCO}_{3}$ particles are, the more fully they participate in the reaction [29].

As shown in Figure $4, \mathrm{NaHCO}_{3}$ affected the combustion of the sucrose dust cloud at the position below the ignition electrode. When the pure sucrose dust cloud was burning, 
the flame spread to the whole glass tube. After adding $\mathrm{NaHCO}_{3}$, the flame of the sucrose dust cloud was basically located above the ignition electrode, and the flame was almost invisible at the bottom of the quartz glass tube, which is mainly because the dust cloud was not uniformly distributed in the glass tube, and the dust distribution concentration varied with the ejection pressure, time and other factors. Overall, the lower part of the glass tube was still the region with high dust concentration, and the concentration of $\mathrm{NaHCO}_{3}$ was high, which had a good inhibiting effect on the dust combustion in this region. For $\mathrm{NaHCO}_{3}$, its decomposition at a high temperature to produce carbon dioxide with density greater than air dilutes the oxygen concentration after settling, and the phenomenon of asphyxiation occurs, which can have an effect on the combustion of sucrose dust in the bottom region.

\section{Discussion}

The inhibition of inert powders is mainly divided into physical and chemical inhibition, and the inhibition of sucrose MIE varies among different types of inert powders [30]. In addition, the particle size is also an important factor influencing the inhibition effect of inert powders.

As shown in Figure 5, the inhibition of sucrose by $\mathrm{NaHCO}_{3}$ is mainly manifested as a combination of physical and chemical inhibition. According to existing studies $[5,10,11,15]$, the inert powder has roughly the same physical inhibition effect on combustible dust, i.e., the inert powder is mixed and uniformly distributed in the mixed dust system, adhering to the surface of the combustible dust or distributed around it, interfering with the heat conduction and thermal radiation processes between the combustible dusts. When the sucrose is ignited, the combustion starts and the heat is transferred to the surrounding area, and the sucrose molecules form a large number of free radicals and are released into the space.. The thermal decomposition temperature of $\mathrm{NaHCO}_{3}$ is low, and decomposition starts at $50{ }^{\circ} \mathrm{C}$ and is complete at $270{ }^{\circ} \mathrm{C}$ [31]. The thermal decomposition of $\mathrm{NaHCO}_{3}$ can absorb heat and reduce the system temperature. At the same time, the products of thermal decomposition can combine with the free radicals produced by sucrose molecules, resulting in the growth rate of sucrose molecule free radicals being lower than its decline rate; thus, the chain reaction of sucrose is inhibited, which shows that the combustion process is affected and the flame intensity becomes smaller.

The thermal decomposition temperature of $\mathrm{NH}_{4} \mathrm{H}_{2} \mathrm{PO}_{4}$ is lower, and it can absorb a large amount of heat in the process of thermal decomposition and affect the normal chain reaction of sucrose combustion. Its inhibition route is similar to that of $\mathrm{NaHCO}_{3}$; the chemical reaction Equations are shown in (1)-(3). However, in terms of its effect on sucrose MIE, $\mathrm{NH}_{4} \mathrm{H}_{2} \mathrm{PO}_{4}$ is far inferior to $\mathrm{NaHCO}_{3}$, but instead has a similar inhibitory effect to $\mathrm{NaCl}$. By analyzing its thermal decomposition process, we can see that $\mathrm{NH}_{4} \mathrm{H}_{2} \mathrm{PO}_{4}$ produces ammonia gas when it is thermally decomposed. Ammonia gas is a combustible gas, which may appear as an "inhibition-enhancement" phenomenon that can encourage the combustion of sucrose [5]. Therefore, when the concentration of $\mathrm{NH}_{4} \mathrm{H}_{2} \mathrm{PO}_{4}$ is low, the concentration of oxygen in the experimental system is not diluted to a certain degree, and the combustion of ammonia will lead to $\mathrm{NH}_{4} \mathrm{H}_{2} \mathrm{PO}_{4}$ exhibiting a less inhibitory effect than $\mathrm{NaCl}$.

$$
\begin{gathered}
\mathrm{NH}_{4} \mathrm{H}_{2} \mathrm{PO}_{4} \Leftrightarrow \mathrm{NH}_{3}+\mathrm{H}_{3} \mathrm{PO}_{4} \\
\mathrm{H}_{3} \mathrm{PO}_{4} \Leftrightarrow \mathrm{H}_{4} \mathrm{P}_{2} \mathrm{O}_{7}+\mathrm{HPO}_{3} \\
\mathrm{H}_{4} \mathrm{P}_{2} \mathrm{O}_{7} \Leftrightarrow \mathrm{P}_{2} \mathrm{O}_{5}+\mathrm{H}_{2} \mathrm{O}
\end{gathered}
$$

$\mathrm{NaCl}$ is non-combustible and does not undergo decomposition reactions, and its inhibition is manifested as physical inhibition, such as cooling and air isolation. It impedes the ignition energy transfer between the sucrose dust and the ignition source. 


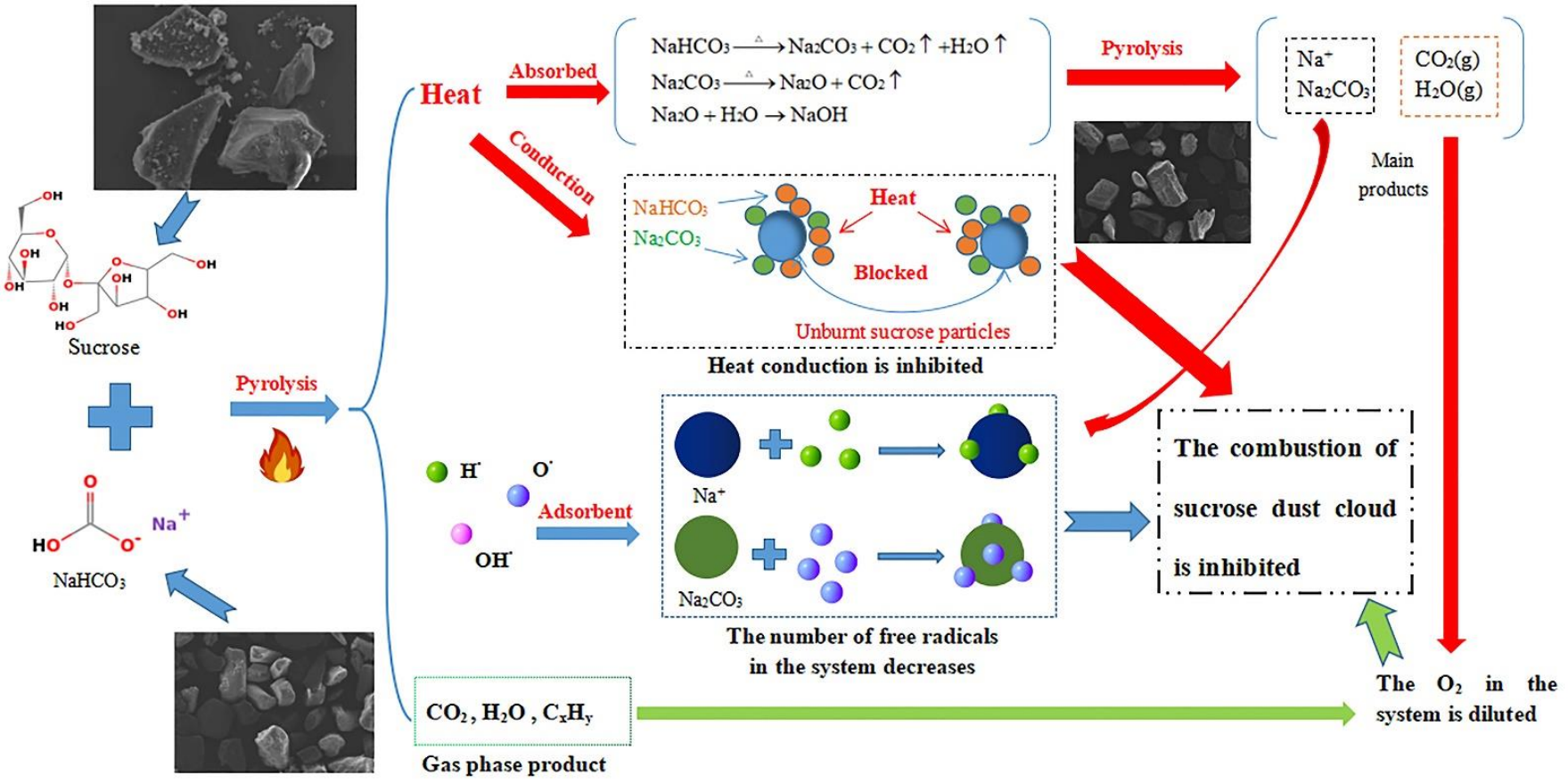

Figure 5. Inhibition mechanism of $\mathrm{NaHCO}_{3}$ on sucrose dust combustion.

As shown in Figure 6, $\mathrm{NaCl}$ was added to the sucrose dust, and after thorough mixing, the $\mathrm{NaCl}$ was dispersed around the sucrose dust. Due to the phenomenon of particle agglomeration, many $\mathrm{NaCl}$ fragments passed through the standard sieve, along with the large particles, to become the experimental sample. After stirring and mixing, many $\mathrm{NaCl}$ fragments were transferred to the sucrose particles and covered the surface of them. After the formation of the combustion flame, the heat conduction rate of the flame front and the intensity of thermal radiation of the combustion particles can be effectively attenuated. On the one hand, the $\mathrm{NaCl}$ particles adhere to the sucrose particle surface; these dispersed $\mathrm{NaCl}$ powders act as a barrier similar to the low temperature. On the other hand, the surface of the $\mathrm{NaCl}$ particles become wet after absorbing water vapor, and the wet surface absorbs more ignition energy, so the remaining ignition energy doesnot ignite the mixed dust.
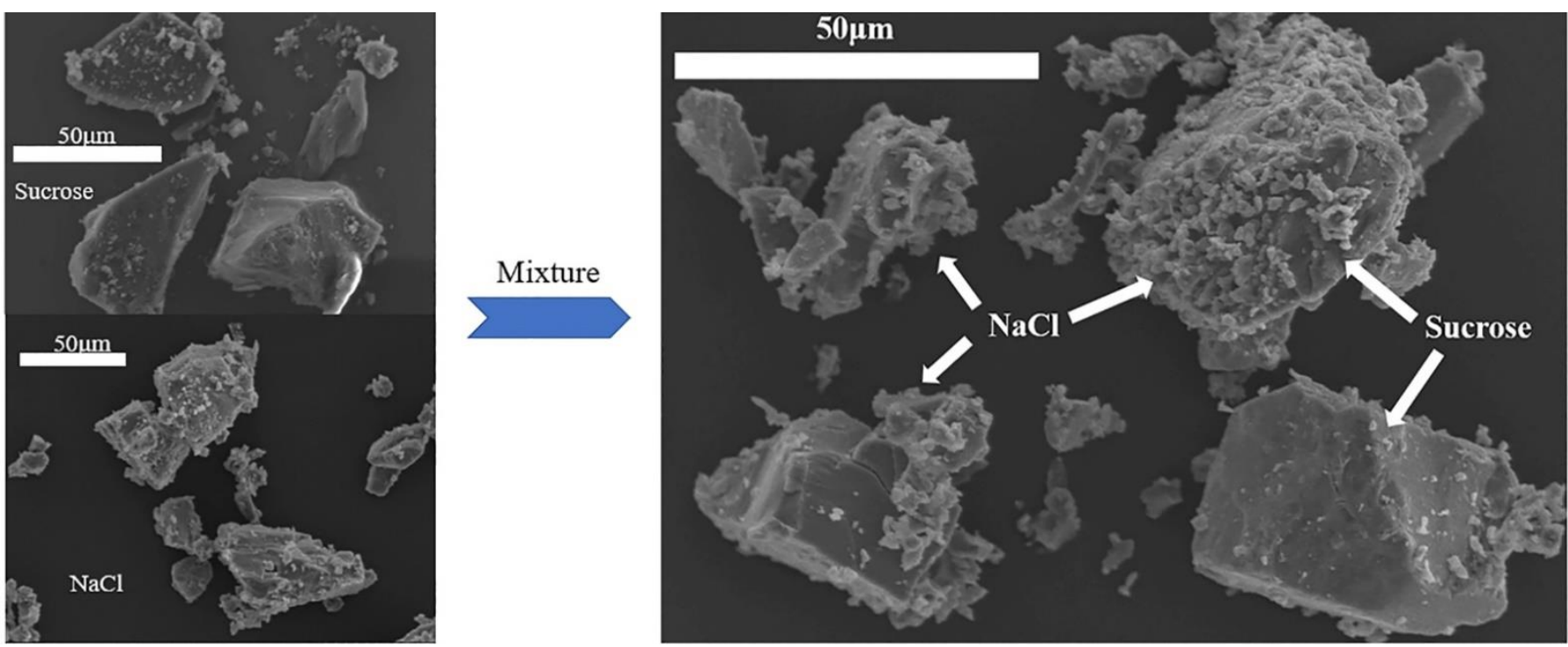

Figure 6. SEM image of $\mathrm{NaCl}$ mixed with sucrose dust. 
$\mathrm{Al}(\mathrm{OH})_{3}$ is a widely used inorganic flame-retardant additive, which starts to decompose water vapor slowly at about $200{ }^{\circ} \mathrm{C}$ [32], and its decomposition and dehydration form is as Equation (4). Due to the short ignition time of the mixed dust, the $\mathrm{Al}(\mathrm{OH})_{3}$ had not yet decomposed in a large amount in the Hartmann tube by the time the combustion had been completed. Therefore, $\mathrm{Al}(\mathrm{OH})_{3}$ mainly behaves as a physical inhibitor. The $\mathrm{Al}(\mathrm{OH})_{3}$ particles increase the MIE of the mixed dust by adhering to the surface of sucrose dust particles and affecting the contact between the sucrose dust particles and oxygen and energy transfer.

$$
\mathrm{Al}(\mathrm{OH})_{3} \Leftrightarrow \mathrm{Al}_{2} \mathrm{O}_{3}+\mathrm{H}_{2} \mathrm{O}
$$

As a whole, the smaller the particle size of the four inert powders, the more uniformly they are distributed in the system, and thus the larger the specific surface area of the particles, the more heat can be absorbed, the faster the heating decomposition, the more decomposition products, and the more significant the effect of inhibition of sucrose dusts.

\section{Conclusions}

In this study, the effects of four different particle sizes of inert powder on the MIE of sucrose dust were studied. The results are as follows:

1. Four kinds of inert powders can enhance the MIE of sucrose dust. After adding inert powder into sucrose, the MIE of sucrose increases. The larger the mass concentration of inert powder, the more significant the increase in the MIE of sucrose dust.

2. The smaller the particle size of inert powder, the more significant its impact on the MIE of sucrose dust. Under the condition of sucrose mass concentration of $417 \mathrm{~g} / \mathrm{m}^{3}$ with a particle size of $48-74 \mu \mathrm{m}$, the mass fractions of $\mathrm{NaHCO}_{3}$ with particle size of $25-37,38-47$ and $48-74 \mu \mathrm{m}$ to prevent sucrose from burning were 20, 20 and $25 \mathrm{wt} \%$, respectively. The mass fractions of $\mathrm{NH}_{4} \mathrm{H}_{2} \mathrm{PO}_{4}$ with particle sizes of 25-37, 38-47 and $48-74 \mu \mathrm{m}$ to make sucrose non-combustion were 30,35 and $40 \mathrm{wt} \%$, respectively. $\mathrm{NaCl}$ with particle sizes of $25-37,38-47$ and $48-74 \mu \mathrm{m}$ made the mass fractions of sucrose non-combustion 35, 40 and $40 \mathrm{wt} \%$, respectively. The mass fractions of 25-37, 38-47 and 48-74 $\mu \mathrm{m} \mathrm{Al}(\mathrm{OH})_{3}$ to make sucrose non-combustion were $60 \mathrm{wt} \%$. The effects of the four inert powders on the MIE of sucrose from strong to weak were $\mathrm{NaHCO}_{3}>\mathrm{NH}_{4} \mathrm{H}_{2} \mathrm{PO}_{4}>\mathrm{NaCl}>\mathrm{Al}(\mathrm{OH})_{3}$.

3. The effects of $\mathrm{NaHCO}_{3}$ and $\mathrm{NH}_{4} \mathrm{H}_{2} \mathrm{PO}_{4}$ on sucrose were mainly in the form of physical heat absorption and chemical reactions, while $\mathrm{NaCl}$ and $\mathrm{Al}(\mathrm{OH})_{3}$ had only physical effects. However, the thermal decomposition of $\mathrm{NH}_{4} \mathrm{H}_{2} \mathrm{PO}_{4}$ produced $\mathrm{NH}_{3}$, which is a combustible gas and may promote the combustion of sucrose, so the inhibitory ability of $\mathrm{NH}_{4} \mathrm{H}_{2} \mathrm{PO}_{4}$ is only slightly better than that of $\mathrm{NaCl}$.

4. In the process of flame propagation, inert powder can slow down the combustion of sucrose dust and reduce the flame height. The area below the ignition electrode of the Hartmann tube device is the area with high inert powder concentration, and there is no flame.

5. $\mathrm{NaHCO}_{3}$ is an effective inert agent to reduce the explosion risk of sucrose powder. The smaller the particle size, the smaller the concentration required for the complete inactivation of sucrose powder. Adding a small amount of $\mathrm{NaHCO}_{3}$ can effectively improve the MIE of sucrose dust.

Author Contributions: Conceptualization, X.L.; methodology, X.L.; investigation, Y.Z., J.J. and S.L.; data curation, Y.Z. and J.J.; visualization, Y.Z. and S.L.; writing-original draft, Y.Z.; writing-review and editing, X.L., Z.Y. and J.S. All authors have read and agreed to the published version of the manuscript.

Funding: This research was funded by Guangxi Natural Science Foundation Project (Grant No. 2020GXNSFAA297037).

Institutional Review Board Statement: Not applicable.

Informed Consent Statement: Not applicable. 
Data Availability Statement: The data presented in this study are available on request from the corresponding author.

Acknowledgments: The authors gratefully acknowledge the financial support from Guangxi Natural Science Foundation Project (Grant No. 2020GXNSFAA297037), and also acknowledge Nanning Sugar Industry Co., Ltd., China, for providing the sucrose dust samples.

Conflicts of Interest: The authors declare no conflict of interest.

\section{Abbreviations}

MIE Minimum Ignition Energy

\section{References}

1. Pe, J.B.V. Imperial sugar refinery combustible dust explosion investigation. Process Saf. Prog. 2011, 30, 66-81. [CrossRef]

2. Yuan, Z.; Khakzad, N.; Khan, F.; Amyotte, P. Dust explosions: A threat to the process industries. Process Saf. Environ. Prot. 2015, 98, 57-71. [CrossRef]

3. Huang, C.; Yuan, B.; Zhang, H.; Zhao, Q.; Li, P.; Chen, X.; Yun, Y.; Chen, G.; Feng, M.; Li, Y. Investigation on thermokinetic suppression of ammonium polyphosphate on sucrose dust deflagration: Based on flame propagation, thermal decomposition and residue analysis. J. Hazard. Mater. 2021, 403, 123653. [CrossRef] [PubMed]

4. Addai, E.K.; Gabel, D.; Kamal, M.; Krause, U. Minimum ignition energy of hybrid mixtures of combustible dusts and gases. Process Saf. Environ. Prot. 2016, 102, 503-512. [CrossRef]

5. Jiang, H.; Bi, M.; Li, B.; Zhang, D.; Gao, W. Inhibition evaluation of ABC powder in aluminum dust explosion. J. Hazard. Mater. 2019, 361, 273-282. [CrossRef]

6. Yang, J.; Yu, Y.; Li, Y.; Zhang, Q.; Zheng, L.; Luo, T.; Suo, Y.; Jiang, J. Inerting effects of ammonium polyphosphate on explosion characteristics of polypropylene dust. Process Saf. Environ. Prot. 2019, 130, 221-230. [CrossRef]

7. Wang, L.; Yuan, B.; Zhang, H.; Jiang, S. Fundamental investigation on the effects of ammonium polyphosphate on flame propagation behaviors of starch dust deflagration. Powder Technol. 2020, 360, 411-420. [CrossRef]

8. Wang, J.; Meng, X.; Yan, K.; Chen, J. Suppression of Aluminum Dust Explosion by $\mathrm{Ca}\left(\mathrm{H}_{2} \mathrm{PO}_{4}\right)_{2} / \mathrm{RM}$ Composite Powder with Core-Shell Structure: Effect and Mechanism. Processes 2019, 7, 761. [CrossRef]

9. Prodan, M.; Ghicioi, E.; Laszlo, R.; Nalboc, I.; Suvar, S.; Nicola, A. Experimental and Numerical Study of Ignition and Flame Propagation for Methane-Air Mixtures in Small Vessels. Processes 2021, 9, 998. [CrossRef]

10. Wang, Q.; Fang, X.; Wen, H.; Shu, C.-M.; Luo, Z.; Xu, Q.; Wang, Q.; Sheng, Y. Explosion hazards of colored powders and the effects of suppressant powder materials. Powder Technol. 2021, 390, 11-19. [CrossRef]

11. Chen, X.; Zhang, H.; Chen, X.; Liu, X.; Niu, Y.; Zhang, Y.; Yuan, B. Effect of dust explosion suppression by sodium bicarbonate with different granulometric distribution. J. Loss Prev. Process Ind. 2017, 49, 905-911. [CrossRef]

12. Lin, C.; Qi, Y.; Gan, X.; Feng, H.; Wang, Y.; Ji, W.; Wen, X. Investigation into the Suppression Effects of Inert Powders on the Minimum Ignition Temperature and the Minimum Ignition Energy of Polyethylene Dust. Processes 2020, 8, 294. [CrossRef]

13. Jiang, H.; Bi, M.; Gao, W.; Gan, B.; Zhang, D.; Zhang, Q. Inhibition of aluminum dust explosion by $\mathrm{NaHCO}_{3}$ with different particle size distributions. J. Hazard. Mater. 2018, 344, 902-912. [CrossRef] [PubMed]

14. Jiang, H.; Bi, M.; Li, B.; Ma, D.; Gao, W. Flame inhibition of aluminum dust explosion by $\mathrm{NaHCO}_{3}$ and $\mathrm{NH}_{4} \mathrm{H}_{2} \mathrm{PO}_{4}$. Combust Flame 2019, 200, 97-114. [CrossRef]

15. Zhao, Q.; Chen, X.; Dai, H.; Huang, C.; Liu, J.; He, S.; Yuan, B.; Yang, P.; Zhu, H.; Liang, G.; et al. Inhibition of diammonium phosphate on the wheat dust explosion. Powder Technol. 2020, 367, 751-761. [CrossRef]

16. Xu, W.; Jiang, Y. Combustion Inhibition of Aluminum-Methane-Air Flames by Fine NaCl Particles. Energies 2018, $11,3147$. [CrossRef]

17. Lin, S.; Liu, Z.; Qian, J.; Zhao, H.; Ali, M.; Gu, Z. Inertant effects and mechanism of $\mathrm{Al}(\mathrm{OH})_{3}$ powder on polyethylene dust explosions based on flame propagation behavior and thermal analysis. Fire Saf. J. 2021, 124, 103392. [CrossRef]

18. Wang, Z.; Meng, X.; Yan, K.; Ma, X.; Xiao, Q.; Wang, J.; Bai, J. Inhibition effects of $\mathrm{Al}(\mathrm{OH})_{3}$ and $\mathrm{Mg}(\mathrm{OH})_{2}$ on $\mathrm{Al}-\mathrm{Mg}$ alloy dust explosion. J. Loss Prev. Process Ind. 2020, 66, 104206. [CrossRef]

19. Castellanos, D.; Bagaria, P.; Mashuga, C.V. Effect of particle size polydispersity on dust cloud minimum ignition energy. Powder Technol. 2020, 367, 782-787. [CrossRef]

20. Bagaria, P.; Hall, B.; Dastidar, A.; Mashuga, C. Effect of particle size reduction due to dust dispersion on minimum ignition energy (MIE). Powder Technol. 2019, 356, 304-309. [CrossRef]

21. Zhou, J.; Jiang, H.; Zhou, Y.; Gao, W. Flame suppression of $100 \mathrm{~nm}$ PMMA dust explosion by $\mathrm{KHCO}_{3}$ with different particle size. Process Saf. Environ. Prot. 2019, 132, 303-312. [CrossRef]

22. Jin, H.; Zheng, L.; Wang, J.; Yu, S.; Pan, R.; Wang, X.; Yang, W.; Fu, Y. Effect of $\mathrm{Al}_{2} \mathrm{O}_{3}$ particle size reduction on aluminium dust explosion. J. Loss Prev. Process Ind. 2021, 70, 104402. [CrossRef]

23. Jiang, H.; Bi, M.; Gao, W. Effect of monoammonium phosphate particle size on flame propagation of aluminum dust cloud. J. Loss Prev. Process Ind. 2019, 60, 311-316. [CrossRef] 
24. Qin, X.; Li, X. Study on fluence of inert dust on minimum ignition energy of sucrose dust. J. Saf. Sci. Technol. 2019, 15, 72-77. (In Chinese) [CrossRef]

25. Wang, F.; Li, X.; Liang, L.; Qin, X.; Qin, S. Study on the effects of $\mathrm{NaCl}$ on minimum ignition energy of sucrose dust. J. Guangxi Univ. (Nat. Sci. Ed.) 2021, 46, 491-497. (In Chinese) [CrossRef]

26. Li, M.; Li, X.; Ding, L.; Liang, L.; Wang, F. Experimental study on minimum ignition energy of sucrose dust. Ind. Saf. Environ. Prot. 2018, 44, 13-15. (In Chinese) [CrossRef]

27. Hosseinzadeh, S.; Norman, F.; Verplaetsen, F.; Berghmans, J.; Bulck, E.V.D. Minimum ignition energy of mixtures of combustible dusts. J. Loss Prev. Process Ind. 2015, 36, 92-97. [CrossRef]

28. Dufaud, O.; Perrin, L.; Bideau, D.; Laurent, A. When solids meet solids: A glimpse into dust mixture explosions. J. Loss Prev. Process Ind. 2012, 25, 853-861. [CrossRef]

29. Kim, W.; Soga, T.; Johzaki, T.; Endo, T.; Kato, T.; Choi, K. Minimum ignition energy and minimum explosible concentration of L-isoleucine and glycine powder. Powder Technol. 2019, 347, 207-214. [CrossRef]

30. Amyotte, P.R. Solid inertants and their use in dust explosion prevention and mitigation. J. Loss Prev. Process Ind. 2006, 19, 161-173. [CrossRef]

31. Wang, Y.; Cheng, Y.-S.; Yu, M.-G.; Li, Y.; Cao, J.-L.; Zheng, L.-G.; Yi, H.-W. Methane explosion suppression characteristics based on the $\mathrm{NaHCO}_{3}$ /red-mud composite powders with core-shell structure. J. Hazard. Mater. 2017, 335, 84-91. [CrossRef] [PubMed]

32. Wang, Q.; Wen, H.; Wang, Q.; Sun, J. Inhibiting effect of $\mathrm{Al}(\mathrm{OH})_{3}$ and $\mathrm{Mg}(\mathrm{OH})_{2}$ dust on the explosions of methane-air mixtures in closed vessel. Sci. China Technol. Sci. 2012, 55, 1371-1375. [CrossRef] 